
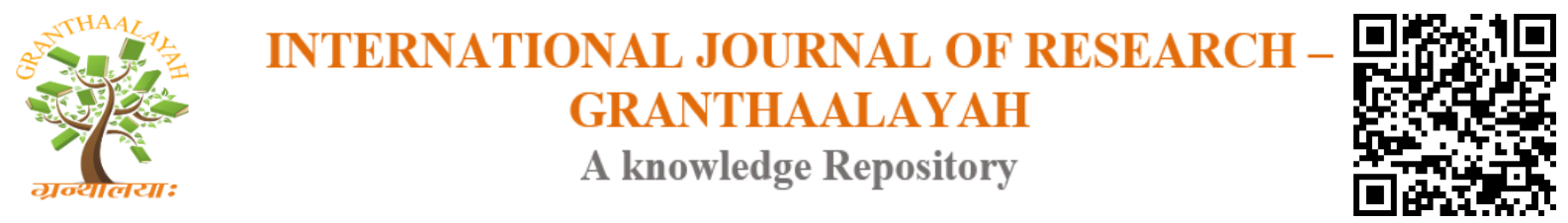

Management

\title{
STRATEGIC CHANGE AND ORGANIZATIONAL TRANSFORMATION PROCESS IN NIGERIAN ORGANIZATIONS
}

\author{
Osagie, Godwin Nosakhare, Ph.D *1 \\ ${ }^{* 1}$ Department of Business Administration, Faculty of Management Sciences, Ambrose Alli \\ University Ekpoma
}

\begin{abstract}
Today's organizations are confronted with the deepest downturn since the great depressions after The World War II. These distortions have necessitated the need for organizations to consider the issue of organizational change. The objective of this study is to examine the impact of strategic change and organizational transformation process in Nigerian organizations; using selected companies from the Telecommunications industry in Nigeria as a case of study. The data collection tool employed by the researcher was the questionnaire approach and the sampling technique employed by the researcher was the Taro Yemmane sampling technique while the hypothesis formulated was tested using the Z-test statistics. The results from the test of the hypothesis showed that strategic change in the Nigerian Telecommunications industry leads to successful organizational transformation. Based on this, the researcher concluded that organizational change can usher in a host of unwelcome and unavoidable side effects and result in the need for the organization to improve productivity, increase morale or re-define the culture of the organization. It was against this backdrop that the researcher recommended that employees need to be allowed to actively take part in meetings and workshops at the onset where the envisaged changes are discussed and management needs to solicit constant feedback from staff throughout the process and take their views into account when restructuring.
\end{abstract}

Keywords: Change; Strategic Change; Organizational Transformation; Organizational Transformation Process.

Cite This Article: Osagie, Godwin Nosakhare. (2018). "STRATEGIC CHANGE AND ORGANIZATIONAL TRANSFORMATION PROCESS IN NIGERIAN ORGANIZATIONS." International Journal of Research - Granthaalayah, 6(9), 116-122. https://doi.org/10.5281/zenodo.1436777.

\section{Introduction}

Modern organizations operate in a global and competitive market, in an ever-changing environment which is often unpredictable. They loose their effectiveness and competitiveness if they follow the traditional way of management of allowing things to go awry before seeking for strategies to confront change (Cao \& McHugh, 2005). Harenstam, Berest, Waldenstrom and 
Scheele (2004) in supporting this opinion, opined that operating markets have radically changed due to globalization, strong competition, technical development and a customer driven market. This demand for change means that organizations must change behaviour and manage to rapidly adapt to shifts in the market (Norrgren, Beer \& Russe, 1996 in Nonas, 2005). At the same time, Beer and Nohria (2000) have shown that currently, many change projects and development programmes produce unsatisfactory results. To increase the ability to change successfully, an organization's change competence must increase; this entails the ability of choosing a change strategy that matches the organization and its member's experiences of change processes (Nonas, 2005).

By and large, this study presents strategic change through the perspectives of systems theories, and underscores that an appreciation of this paradigm can aid organizational leaders in responding more effectively to the environmental uncertainties of contemporary organizations. It identified the critical determinants of organizational success and failure which are significant in understanding how strategic change and organizational transformation may be managed more effectively in the Nigerian Telecommunication industry that has experienced changes in strategies, markets, ownership and management as a result of reforms in the sector. This has created a boom in the sector and the need for change so as to survive the turbulent global business environment in information and computer technology (ICT).

\section{Statement of the Problem}

Today's organizations are confronted with the deepest downturn since the great depressions after The World War II. These distortions have necessitated the need for organizations to consider the issue of organizational change. Thus it could be argued that organizations are only as successful as their readiness to respond to changes in their environment and to adapt their internal strategies and functions accordingly. This dynamic nature of the environment in which organizations operate, has become a major concern that organizations in the Nigerian setting do not seem to be responding successfully to. Unsuccessful change efforts not only jeopardize an organization's chances of remaining in business or maintaining competitive advantage, it may leave managers frustrated and employees cynical adding to the difficulty of the next round of change.

The Telecommunication industry in Nigeria is not left behind in this wave of change and change management; as they are a key infrastructure of economic and social development for the $21 \mathrm{st}$ Century. They provide, as facilitator, an enabling condition for carrying on the dominant pursuits of the modern day Information Age. The objective of this study is to examine the impact of strategic change and organizational transformation process in Nigerian organizations; using selected companies from the telecommunications industry in Nigeria as a case of study. Specifically, the objective of this study was to examine how firms undergoing strategic change realize success in their organizational transformation efforts.

\section{Research Hypothesis}

In line with the specific objective of the study, the hypothesis was formulated and tested. 
$\mathrm{H}_{0}$ : Strategic change efforts in the Nigerian Telecommunication industry leads to successful organizational transformation programmes in the industry.

\section{Review of Related Literature}

Since the recent past, the market place has demanded quality in products and services. Organizations had to distinguish themselves from their competitors through excellence as markets opened up and competition became fierce. In today's environment, the ability of organizations to respond to micro-markets' demands, where choice to the consumer is preponderant, will depend on their ability to be flexible. "The transitory nature of market demands is an important reason that [change and] flexibility ought to be a defining characteristic of organizational effectiveness" (Volberda, 1992). Therefore, from an organizational perspective flexibility can be defined as the ability to react to change.

Like the ancient Greek philosophers, contemporary theoreticians do not agree on what "is" change. Instead of defining change as a transformation from one state to another, which would be logically circuitous, this thesis is intended to depict the characteristics of its manifestations in order to develop a framework for further discussion. Accordingly, this chapter examines in detail the subject of change, the different types and triggers of change, existing models and theories of change, the management and implementation of change, relationship between strategic change and organizational transformation, strategic change as related to our case study telecom firms (Multilinks, Zoom Mobile and Airtel).

Organizational leadership was addressed within the context of strategic change; the impact of strategic change on organizational and individual productivity will also be highlighted; finally, a model that explains the relationships between strategic change and organizational transformation is presented. The discussion on strategic organizational change will be concluded by suggesting a need to develop more comprehensive models to study the impact of change on organizations.

\section{Theoretical/Empirical Framework}

The theoretical framework on which this study is based is the General Systems Theory (GST) which was originally proposed by the biologist Ludwig von Bertalanffy (1968). The study of systems can follow two general approaches: a cross-sectional approach, which deals with the interaction between two systems, and a developmental approach which deals with the changes in a system over time (Walonick, 1993). This study followed both the cross-sectional approach and the developmental approach methods of Systems Theory.

This choice of framework was because the theory provided a link between the approach to be used in examining our studies and the body of existing literature; it defined the relationship between the theoretical foundations of the research with what the researcher wanted to do. Infact Katz and Kahn (1978) summarized the idea of systems theory as a knowledge framework that focuses on structures, relationships, and interdependence between elements (Katz and Kahn, 1978). This in essence described the span of focus of this research, making the General Systems Theory framework an ideal and preferred choice for our study. 
Two major studies are germane in this investigation. The first is the study by Devos and Buelens (2003) who investigated the contribution of three important factors to openness to change, the content of organizational change, the context in which the change occurs and the process of the organizational change. The use of experimental design allowed them to be able to manipulate the conditions of organizational change and their impact on the participants' openness to change. Supporting our expectations, they found that openness to change is facilitated by a non-threatening organizational change (content), trust in management (context), a positive track record of past changes in the organization (context) and opportunities to participate (process).

Secondly, Khan and Rehman's (2008) empirical study was based on a Swedish firm operating in a developing economy, which was under severe pressure from external environment and internal problems, which made it very important for its survival to introduce a major change program. The firm understudy proposed a change program but it was severely resisted by its employees and the change brought very negative results, opposite to its demands. Looking at the possible solutions discussed in the literature of change management, every measure has been applied by the experienced management of the firm to overcome resistance, but this failed.

\section{Research Methods}

The descriptive survey research design method that entailed a survey that involves the collection of data from selected individuals in a single time period (no matter how long it takes to collect data from participants) was applied in this study. The population for this study is made up of 2520 management, managerial and supervisory level staff as provided by the Human Resources Departments of the selected Nigerian Telecommunication Companies (Airtel Nigeria Limited, Multilinks Nigeria Limited and Zoom Mobile Nigeria Limited) that were selected for this study. This is shown in Table 1

Table 1: Number of management/managerial and supervisory level staff of firms understudy

Source: Field Survey 2016

\begin{tabular}{|l|l|}
\hline Firm & Number of staff \\
\hline Airtel Nigeria Ltd & 1235 \\
\hline Mulit-Links Nigeria Ltd & 580 \\
\hline Zoom Mobile Nigeria Ltd & 705 \\
\hline Total & $\mathbf{2 5 2 0}$ \\
\hline
\end{tabular}

The researcher determined his sample size by using Taro Yamane Formula. According to Yamane (1973), to determine the adequate sample that would be representative of a finite population, the sample size (n) can be computed from the $\mathrm{N}$ (population) using the formula as slated:

Where:

$$
n=\frac{N}{1+N(e)^{2}}
$$

$\mathrm{n}=$ Sample size

$\mathrm{N}=$ Population size

$\mathrm{e}=$ error limit

Using the population of the region as given above with 
$\mathrm{n}=$ representing the sample size

$\mathrm{N}=$ Representing the population

$\mathrm{e}=$ representing the margin of error

Thus, $\mathrm{N}$ the others. $=2520$

$\mathrm{e}=0.05$ and $\mathrm{e}^{2}=0.025$

$\mathrm{n}=\underline{2520}$

$1+\overline{2520}(0.05)^{2}$

$\mathrm{N}=345.2054$

Based on this, 345 questionnaires were distributed.

The face validation of the questionnaire was done by experts in Business Administration. The Cronbach's reliability technique was used to determine the reliability of the instrument. A Cronbach alpha of 0.723 was obtained for the research instrument and the value was seen to be large enough to consider the instrument reliable. The result as obtained from the Statistical Packages for Social Sciences (SPSS) version 17 is shown in Table 2.

Table 2: Reliability Statistic

\begin{tabular}{|l|l|l|}
\hline Cronbach's Alpha & Cronbach's Alpha Based on Standardized Items & N of Items \\
\hline .723 & .727 & 40 \\
\hline
\end{tabular}

Source: Field Survey 2012

The Z-test statistics using the Statistical Packages for Social Sciences (SPSS) version 17 was used to test the formulated hypothesis.

\section{Results}

Results from the test of hypothesis is given below

\section{Test of Hypothesis}

$\mathrm{H}_{0}$ : Strategic change efforts in the Nigerian Telecommunication industry leads to successful organizational transformation programmes in the industry.

Table 3: test summary for hypothesis

\begin{tabular}{|c|c|c|c|c|c|c|}
\hline \multicolumn{4}{|c|}{ A: } & \multicolumn{3}{|c|}{ One-Sample Statistics } \\
\hline & $\mathbf{N}$ & \multicolumn{2}{|c|}{ Mean } & Std. Deviation & \multicolumn{2}{|c|}{ Std. Error Mean } \\
\hline Mean section IIA & 300 & \multicolumn{2}{|c|}{3.684} & .439 & \multicolumn{2}{|c|}{.025} \\
\hline \multicolumn{7}{|c|}{ One-Sample Test } \\
\hline & \multicolumn{6}{|c|}{ Test Value $=3$} \\
\hline & \multirow[t]{2}{*}{$\mathrm{Z}$} & \multirow[t]{2}{*}{ df } & \multirow[t]{2}{*}{ p-value } & \multirow[t]{2}{*}{ Mean Difference } & \multicolumn{2}{|c|}{$\begin{array}{l}\text { 95\% Confidence Interval of the } \\
\text { Difference }\end{array}$} \\
\hline & & & & & Lower & Upper \\
\hline Mean section IIA & 26.930 & 299 & .000 & 684 & .634 & .734 \\
\hline
\end{tabular}

Source: Authors's computation from SPSS package 
From Table 3 above result showed a mean score of 3.684 and standard deviation of .439 while the $\mathrm{Z}$ score was 26.930 which showed the hypothesis is significant. The Z-score is statistically significant since the $\mathrm{p}$-value of 0.000 is less than 0.05 level of significance (i.e $\mathrm{p}<0.05$ ). Thereby the null hypothesis is rejected. This implies that strategic change efforts in the Nigerian Telecommunication Industry leads to successful organizational transformation programmes in the Industry.

\section{Summary of Findings}

The results from the test of the hypothesis showed that strategic change in the Nigerian Telecommunication industry leads to successful organizational transformation. This result is in line with the work of Robbins (2003) and Branch (2002) who had earlier noted that change leads to multi-dimensional, multi-level, discontinuous, radical transformation that involves the reframing assumptions about the organization and the world in which it operates. Majority of scholars have differentiated widely in various literature that organizational transformation is notably different from strategic change or any other forms of change. Keene (2000) stated that change is seen as necessary merely to survive while transformation is required to thrive and a constant need for reinvention is needed to secure long-term success.

Beckhard (2002), Toombs and Humphreys (2007) have also noted that Organizations are transformed by developing (and deploying) new visions, missions, values, goals, strategies and structures that reflect a continuously-changing organization and the capability for ongoing, radical self-transformation and reinvention. Head (1997) also asserted that transformation occurs only when an organization taps into the complete potential of human resources and align both the structural and cultural processes involved with the overall goals of the organization.

\section{Conclusion}

The ability to change is a critical competency for successful organizations. Many things that can influence and trigger change initiatives include: downsizing, corporate growth, acquisitions, mergers, a change in senior executives, need for innovation, implementation of project management and quality improvement initiatives. Organizational change can usher in a host of unwelcome and unavoidable side effects and result in the need for the organization to improve productivity, increase morale or re-define the culture. Organizational change is a strategic imperative in today's global and fast-paced environment. Unfortunately, in the pursuit of change, of trying to be the best, of standing out from the pack, seeking higher levels of status and power, managers and leaders in organizations urgently and impatiently clamor for the "latest and greatest ideas." In their haste, they forget the fundamental and sound principles which are prerequisites for a successful change to occur - and wonder why they are not making progress. Although managing change is difficult, implementing these few tried and true principles can help managers and leaders improve the organization's success.

\section{Recommendations}

The following are therefore recommendations for management; based on this research findings. 
1) Employees need to be allowed to actively take part in meetings and workshops at the onset where the envisaged changes are discussed. This will make them more supportive of the restructuring process and therefore prevent any possible resistance to change, and make them believe that they are an extrinsic part of the change process.

2) The possible benefits of restructuring to employees need to be personally discussed with individuals.

3) Management needs to solicit constant feedback from staff throughout the process and take their views into account when restructuring.

\section{References}

[1] Beckhard, R. (2002). The healthy organization: The organization of the Future, (The Drucker Foundation, Frances Hesselbein, Marshall Goldsmith, and Richard Beckhard, Editors), San Francisco: Jossey Bass Publishers, 325-328.

[2] Beer, M. \& Nohria, N. (2000). Breaking the code of change. Boston: Harvard Business School Press.

[3] Branch K. M. (2002). Change management, Retrieved December 18, 2006, from http://www.wrennetwork.net/resources /benchmark-changemanagement.pdf.

[4] Cao, G \& McHugh, M. (2005). A systemic view of change management and its conceptual underpinning. Systemic Practice and Action Research, 18(5), 475-490.

[5] Devos, G. \& Buelens, M. (2003). Openness to organizational change: The contribution of content, context and process. Vierick Leuven Gent Working Paper Series, Series 6. Gothenburg: Vierick Leuven Gent Management School Press.

[6] Harenstam, A., Bejerot, E. Waldenstrom, K. \& Scheele, P. (2004) Multi-level analysis of organisational change and working conditions in public and private sector; European Journal of Work and Organisational Psychology, 13(3), 60-77.

[7] Head, C.W. (1997). Beyond corporate transformation: A whole systems approach to creativity and sustaining high performance. Portland: Productivity Press.

[8] Katz, D. \& Kahn, R. (1978). The social psychology of organizations, New York: Wiley.

[9] Khan, K \& Rehman, M (2008). Employees' resistance towards organizational change. New York: Wiley.

[10] Nonas, M. (2005). Overcoming resistance to change. Beverley Hills, CA: Roundtable Publications.

[11] Norrgreen, N., Beer, M. \& Russe S. (1996). Making it happen: leadership and the practice of strategy. Stockholm: Sweden.

[12] Volberda, H. W., (1992), Organizational flexibility change and preservation: A flexibility audit and redesign model, Noordhoff: Wolters.

[13] Von Bertalanffy, L. (1968). General systems theory: Foundations, developments, applications. New York, NY: Braziller.

*Corresponding author.

E-mail address: nosagosagie4rea@ yahoo.co.uk 